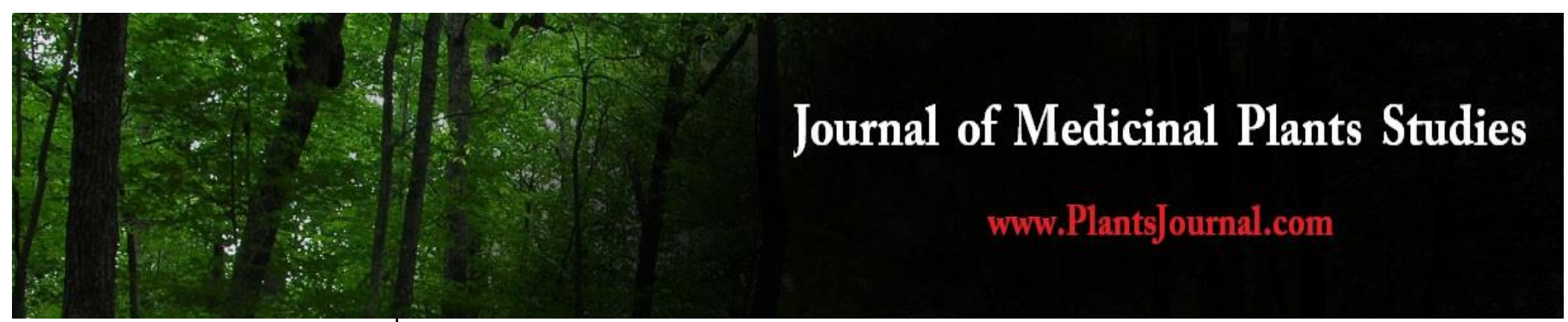

ISSN (E): 2320-3862

ISSN (P): 2394-0530

NAAS Rating: 3.53

www.plantsjournal.com

JMPS 2020; 8(6): 94-98

(C) 2020 JMPS

Received: 07-09-2020

Accepted: 09-10-2020

Remya A

Department of Pharmacognosy,

Siddha Central Research

Institute (CCRS, Ministry of

AYUSH, Govt of India),

Arumbakkam, Chennai,

Tamil Nadu, India

Sunil Kumar KN

Department of Pharmacognosy,

Siddha Central Research

Institute (CCRS, Ministry of

AYUSH, Govt of India),

Arumbakkam, Chennai,

Tamil Nadu, India
Corresponding Author: Sunil Kumar KN

Department of Pharmacognosy,

Siddha Central Research

Institute (CCRS, Ministry of

AYUSH, Govt of India),

Arumbakkam, Chennai,

Tamil Nadu, India

\section{A review on critically endangered species of Acanthacea: Justicia beddomei (Clarke) bennet: An immune booster}

\section{Remya A and Sunil Kumar KN}

DOI: $\underline{\text { https://doi.org/10.22271/plants.2020.v8.i6b.1232 }}$

\begin{abstract}
Justicia beddomei (Clarke) Bennet, a member of Acanthaceae, is endemic to the Southern Western Ghats. This plant shows remarkable similarities with $J$. adhatoda L., and the only morphological difference is the smaller size of both leaves and inflorescence. J. beddomei has an abundance of phytochemicals and widely used in traditional medicinal systems such as Ayurveda, Siddha and Unani. The phytochemicals present in the spewcies possess immense anti-bacterial, cytotoxic, anthelmintic, analgesic, antioxidant activities. Vasicoline, a major phytochemical proved for the treatment for Covid 19. At present, the plant is listed under IUCN Red List as Critically Endangered category. Protecting species from extinction, enhancing ecosystem services and protecting biological diversity are important for maintaining a healthy ecosystem. The review reveals the importance of conservation of this plant for the fitness of the ecosystem and the development of traditional medicine for the future.
\end{abstract}

Keywords: Adathodai, critically endangered, conservation, substitute, Vasaka

\section{Introduction}

India's traditional medicinal system flourished because of the diversity and abundance of medicinal plants. These plants and their derived parts play a key role in the treatment of several ailments of human beings. Nearly 1500 and 1200 species of plants are used in drug preparation for Ayurveda and Siddha respectively ${ }^{[1]}$. Acanthaceae is a large family of dicotyledonous plants comprising of more than 4300 species and distributed worldwide having a lot of medicinally important plants ${ }^{[2]}$. The largest member of this family is Justicia which comprises about more than 600 species distributed in the tropical and pantropical regions, nearly 50 species occur in India and are distributed in the temperate regions ${ }^{[3,5]}$.

$J$. beddomei is endemic to the Southern Western Ghats in locations like Kerala, Valparai (South Arcot), Akkamalai (Coimbatore) and Mahendragiri (Kanniyakumari) ${ }^{[6]}$. It is included in the IUCN Red List category as Critically Endangered Species ${ }^{[7]}$. The plants are commonly known as Malabar Nut because of the resemblance with $J$. adhatoda. It is morphologically similar to J. adhatoda and the only visible difference is the smaller size of leaves and terminal spike inflorescence with more tailed anthers ${ }^{[8]}$. J. beddomei, very commonly used in the traditional medicinal systems like Ayurveda, Siddha and Unani as diuretic, antispasmodic, expectorant, anti-asthmatic, febrifuge, styptic and tonic ${ }^{[9]}$. The leaves are very effective for the treatment of irritable cough, diarrhoea and haemoptysis ${ }^{[10]}$. The medicinal properties of plants are broadly used for the treatment of leprosy, blood disorders, heart troubles, thirst, fever, vomiting, cough, asthma ${ }^{[11]}$, diseases of eyes, bleeding diarrhoea, dysentery, bronchitis, inflammation, jaundice, tumours, mouth-troubles, sore-eye, gonorrhoea, tuberculosis, haemorrhage and haemorrhoids ${ }^{[12]}$.

The prevailing status of this plant reveals that the unconstrained use of natural products inversely affects the balance of the ecosystem. Crucial conservation of the ecosystem is important for the healthy existence of each member.

\section{Scientific classification}

Kingdom: Plantae

Division: Angiosperms 
Class: Asterids

Order: Lamiales

Family: Acanthaceae

Genus: Justicia

Species: J. beddomei

\section{Common names}

English: Malbar Nut

Hindi: Adusa, arusa

Kannada: Sann-adusoge, aadusoge, addalasa, addasara, byaaladamara, vaasa

Malayalam: Cheriyaatalotakam, cittatalotakam

Sanskrit:Vasa, vrsah

Tamil: Adutota, cittadalodakam

Telugu: Addasaramu

\section{Habit}

These are large diffusely branched shrubs wit cylindrical striated stem with swollen nodes. The simple leaves arranged opposite and nearly 5 to $10 \mathrm{~cm}$ long and 3 to $4 \mathrm{~cm}$ wide and glabrous; apex ovate to acuminate with entire margin; base acute and petiole short; 8 paired main nerves arranged laterally.

The flowers are small terminal spikes; calyx with 5 sepals of $5 \mathrm{~mm}$ in length; petals $1.25 \mathrm{~cm}$ long with 2 lips; pubescent outside and dull white in colour; upper lip emarginated and deflexed lower lip with 3 lobes; 4 stamens with hairy filaments at the base; 2 celled ovary and each cell with 2 ovules; style pubescent. Fruit a clavate capsule with a long solid base and the seeds 1 or 2, suborbicular, compressed and rugose ${ }^{[13,14]}$.

\section{Pharmacognosy}

Pharmacognostical studies are the easiest way to sort out morphologically similar adulterant/substitute plants used in the medicinal system. J. beddomei and J. adhatoda are morphologically similar and the one who is unaware of plants will misidentify these two. The characteristic features of the family Acanthaceae are the presence of cystoliths in leaf lamina and petiole. But in J. beddomei these characteristic cystoliths are absent ${ }^{15}$. There is no further anatomical or pharmacognostical studies about this plant reported yet.

\section{Phytochemicals}

Preliminary phytochemical analysis of the plant J. beddomei reported various types of phytochemicals. The phytochemical investigation of different parts revealed the presence of the bioactive compounds like alkaloids, tannins, disaccharides, flavonoids, phenolics and glycosides ${ }^{[16,17]}$. The important biologically active chemicals and their properties are tabulated in Table 1. The chemicals in which detailed pharmacological studies are not carried out are 7-octadecyne; 2-methyl, 9,12,15-octadecatrienal; $\beta$-sophoroside; anisotine; hexadecanoic acid, ethyl ester; phosphoric acid, diethyl pentyl ester; flavonoids like luteolin; alkane like tritriacontane; quinazoline alkaloid like adhavasinone, deoxyvasicinone, vasakin, vasicinine, vasicinol, vasicinolone, vasicol, vasicolinone, vasicolone and Vasicine ${ }^{18-21}$.

Table 1: Chemicals and properties of Justicia beddomei (Clarke) Bennet

\begin{tabular}{|c|c|c|c|}
\hline SN & Chemicals & Chemical formula & Property \\
\hline 1. & $\begin{array}{l}\text { 1,2-Benzenedicarboxylic acid, } \\
\text { mono(2-ethylhexyl ester) }\end{array}$ & $\mathrm{C}_{16} \mathrm{H}_{22} \mathrm{O}_{4}$ & Cytotoxic $^{[22]}$ \\
\hline 2. & Adhatodic acid ${ }^{[18]}$ & - & $\begin{array}{c}\text { Tuberculosis, sore throat }{ }^{[23]} \text {, expectorant, bronchodilator, antibacterial }{ }^{[24]} \text {, } \\
\text { antiasthmatic }{ }^{[25]}\end{array}$ \\
\hline 3. & Adhatodine $^{[18]}$ & $\mathrm{C}_{20} \mathrm{H}_{21} \mathrm{~N}_{3} \mathrm{O}_{2}$ & Anti-malarial $^{26}$ \\
\hline 5. & Aminophylline ${ }^{[18]}$ & $\mathrm{C}_{16} \mathrm{H}_{24} \mathrm{~N}_{10} \mathrm{O}_{4}$ & $\begin{array}{c}\text { Asthma or other chronic lung diseases like chronic bronchitis and emphysema, } \\
\text { prevent apnea in preterm infants }{ }^{[27]} .\end{array}$ \\
\hline 6. & Campesterol ${ }^{[21]}$ & $\mathrm{C}_{28} \mathrm{H}_{48} \mathrm{O}$ & Lowering LDLs and cholesterol ${ }^{[28]}$ \\
\hline 7. & Carotene $^{[18]}$ & $\mathrm{C}_{40} \mathrm{H}_{\mathrm{x}}$ & Precursor of vitamin $\mathrm{A}^{[29]}$, anti-cancer ${ }^{[30]}$, antioxidant ${ }^{[31]}$ \\
\hline 9. & Kaempferol ${ }^{[18]}$ & $\mathrm{C}_{15} \mathrm{H}_{10} \mathrm{O}_{6}$ & $\begin{array}{l}\text { Antioxidant by reducing oxidative stress, antibacterial agent, human xenobiotic } \\
\text { metabolite, blood serum metabolite, urinary metabolite and currently under } \\
\text { consideration as a possible cancer treatment }{ }^{[32]}\end{array}$ \\
\hline 10. & Lupeol ${ }^{[18]}$ & $\mathrm{C}_{30} \mathrm{H}_{50} \mathrm{O}$ & Anti-cancerous ${ }^{[33]}$ \\
\hline 11. & $\begin{array}{l}\text { O-Ethyl S-2-dimethylaminoethyl } \\
\text { methylphosphonothiolate }{ }^{[21]}\end{array}$ & $\mathrm{C}_{7} \mathrm{H}_{18} \mathrm{NO}_{2} \mathrm{PS}$ & Used as a quick-acting military chemical nerve agent ${ }^{[34]}$. \\
\hline 12. & Phytol ${ }^{[21]}$ & $\mathrm{C}_{20} \mathrm{H}_{40} \mathrm{O}$ & $\begin{array}{c}\text { Antinociceptive, antioxidant }{ }^{35} \text {, anti-inflammatory, anti-allergic }{ }^{[36]} \text {, immunostimulant, } \\
\text { activation of both innate and acquired immunity }{ }^{[37]} \text {. }\end{array}$ \\
\hline 13. & Squalene ${ }^{[21]}$ & $\mathrm{C}_{30} \mathrm{H}_{50}$ & $\begin{array}{l}\text { Advantages for the skin as an emollient and antioxidant, and for hydration and its } \\
\text { antitumor activities }\end{array}$ \\
\hline 14. & Stigmasterol ${ }^{[21]}$ & $\mathrm{C}_{29} \mathrm{H}_{48} \mathrm{O}$ & $\begin{array}{l}\text { Maintain the structure and physiology of cell membrane }{ }^{[39]} \text {, lowering the levels of } \\
\text { LDLs }{ }^{[40]}\end{array}$ \\
\hline 15. & Vasicine (peganine) ${ }^{[19]}$ & $\mathrm{C}_{11} \mathrm{H}_{12} \mathrm{~N}_{2} \mathrm{O}$ & $\begin{array}{c}\text { Bronchodilator activity in-vitro and in vivo }{ }^{[41]} \text {, uterine stimulant, respiratory } \\
\text { stimulant, cardiac depressant (combined with vasicinone) }{ }^{[42]}\end{array}$ \\
\hline 16. & Vasicinone $^{[20]}$ & $\mathrm{C}_{11} \mathrm{H}_{10} \mathrm{~N}_{2} \mathrm{O}_{2}$ & Bronchodilatory (in vitro) bronchoconstictory (in vivo) ${ }^{[43]}$, antianaphyactic ${ }^{[44]}$ \\
\hline 17. & Vasicoline $^{[18]}$ & $\mathrm{C}_{19} \mathrm{H}_{21} \mathrm{~N}_{3}$ & Effect for the treatment for COVID 19, diseases related to respiratory problems ${ }^{[45]}$ \\
\hline 18. & Vitamin E [21] & $\mathrm{C}_{29} \mathrm{H}_{50} \mathrm{O}_{2}$ & Antioxidant ${ }^{[46]}$ \\
\hline 19. & Vitamin C ${ }^{[18]}$ & $\mathrm{C}_{6} \mathrm{H}_{8} \mathrm{O}_{6}$ & Antioxidant $^{[47]}$ \\
\hline 20. & $\beta$-Sitosterol ${ }^{[19]}$ & $\mathrm{C}_{29} \mathrm{H}_{50} \mathrm{O}$ & $\begin{array}{c}\text { Antiinflammatory }^{48} \text {, chemoprotective }{ }^{[49]} \text {, hypocholesterolemic }{ }^{[50]} \text {, } \\
\text { immunomodulatory }\end{array}$ \\
\hline
\end{tabular}

\section{Pharmacological activities}

$J$. beddomei has a predominant role in the traditional medical systems in India. The pharmacological activities are studied for the further development of drug research. The following activities of the plant are studied.

\section{Anthelmintic activity}

The antihelminthic activity of ethanolic as well as chloroform extract of $J$. beddomei leaves was tested against Indian earthworms. Different doses of $10 \mathrm{mg} / \mathrm{ml}, 20 \mathrm{mg} / \mathrm{ml}$ and 50 $\mathrm{mg} / \mathrm{ml}$ of each extract were tested and compared with the 
standard drug Piperazine citrate. The result observed that the death/paralysis of the worms increased with increasing concentration. Effectiveness of the extracts was inversely proportional to the time taken for paralysis of the worms. The $50 \mathrm{mg} / \mathrm{ml}$ ethanolic extract was more efficient than the chloroform extract for the killing of worms. The current study suggested that the ethanolic extract may be effective against the worms in human ${ }^{[52]}$.

\section{Analgesic activity}

The analgesic activity of different concentration of ethanolic extract of $J$. beddomei leaves was evaluated in albino rats using Eddy's hot plate method [54]. The activity of the 100 $\mathrm{mg} / \mathrm{kg}$ and $50 \mathrm{mg} / \mathrm{kg}$ was compared with the standard 15 $\mathrm{mg} / \mathrm{kg}$ morphine sulphate. The result showed that the 90 minutes administration of test extract of $100 \mathrm{mg} / \mathrm{kg}$ possesses significant analgesic activity. Due to the presence of alkaloids, carbohydrates and tannins, the extract engenders noticeable analgesic effect. The exact modes of action of the biologically active compound responsible for the activity are not studied, which minimise the efficacy of the results ${ }^{53}$.

\section{Antioxidant activity}

The powdered aerial parts of J.beddomei were extracted using petroleum ether, chloroform, ethyl acetate and methanol. Standard protocols followed for screening the preliminary phytochemicals. The tests like DPPH, hydroxyl radical, superoxide anion radical scavenging abilities, $\beta$-carotenelinoleic acid model, reducing power ability, nitric oxide scavenging assay of all the extracts were evaluated for analyzing their potential antioxidant activities. The results were compared with ascorbic acid, Butylated hydroxytoluene and catechin standards and the concentration and efficacy were directly proportionate. Because of the presence of phenolic and flavonoid, all the extracts showed strong antioxidant activity ${ }^{[16,21]}$.

\section{Anti-cancer and XOI activities}

In vitro anticancer and xanthine oxidase inhibitory (XOI) activities were investigated with the methanolic extract of dried aerial parts of $J$. beddomei which was compared with the standard 2.4-40 $\mu \mathrm{g} / \mathrm{ml}$ Allopurinol. The extract was exposed to MTT colourimetric assay in HeLa and MCF-7 cell lines for XOI activity and cytotoxic activity. Increased dosage of the methanolic extract showed increased anticancer and XOI activities $(200 \mu \mathrm{g} / \mathrm{ml}$ and $40 \mu \mathrm{g} / \mathrm{ml}$ respectively). The presence of flavonoids and phenolic compounds of the extract contributed towards the inhibitory activities against cancer and Xanthine Oxides ${ }^{[54]}$.

\section{Anti-diabetic activities}

Whole plant ethanolic extract induced to the alloxan-induced diabetic rats showed a reduction of diabetes in rats. Further studies needed for the identification of specific phytochemicals involved in this ${ }^{55]}$.

\section{Cytotoxic activity}

Endophytes are known for their cytotoxic activities. The endophytes found in $J$. beddomei were tested for its cytotoxicity. Ethyl extracts of the plant J. beddomei and its endophytic fungi showed cytotoxic activity. The preliminary phytochemicals were screened out and the MTT assay of the extract was carried out on lung adenocarcinoma cells. The results revealed that the bioactivity was three times than that of the host plant. Endophytes are known for the production of novel secondary metabolites with a broad spectrum of activity according to their host. Aspergillus fumigates found in $J$. beddomei increased the cytotoxicity ${ }^{[56]}$.

\section{Other activities}

The pharmacologically active phytochemicals present in this plant revealed important activities like antipyretic, antiinflammatory, anthelmintic, antiseptic, antidiabetic, blood coagulant, a bronchodilator, disinfectant, antioxidant, hepatoprotective, anti-jaundice, expectorant and has many other medicinal applications ${ }^{[57,60]}$. The unavailability and the increasing demand of the plant may have reduced further studies.

\section{Molecular studies}

The morphological characters of $J$. adhatoda and J. beddomei are almost similar. It is very difficult to distinguish them based on the taxonomic or phenotypic characters. Analyzing the molecular aspects is the correct identification strategies in such cases. PCR-RFLP of selected nuclear ribosomal ITS amplicon along with sequence variability was used for the molecular studies. The already sequenced J. adhatoda was reported in NCBI as $687 \mathrm{bp}$ and the direct sequencing of the gel-purified ITS amplicon yielded a 624 bp sequence for $J$. beddomei. It is clear that through the phylogenetic tree $J$. beddomei and $J$. adhatoda were sister groups and distinct species with common ancestors. The ITS sequences of $J$. beddomei and J. adhatoda contained unique recognition sites for specific restriction enzymes for which all the species were distinct in their PCR-RFLP patterns. When the ITS amplicons of the four selected Justicia species were subjected to restricted digestion with EcoRI or SfoI, it yielded the expected restricted products. The ITS sequences and PCRRFLP were successful in resolving the ambiguity that existed among the species of Justicia ${ }^{[61]}$.

\section{Propagation}

Seed germination and stem cutting are the main propagules for J. beddomei. Studies showed that seed germination and propagation through stem cutting are very low ${ }^{[62]}$. Micropropagation ways like tissue culture are the easiest way to propagate these type of plants. Rapid propagation through nodal explants in MS medium supplemented with BAP achieved shoot multiplication. Increasing concentration of BAP resulted in an increase in shoot development and IAA and NAA concentration affected the root development. It was suggested that hardening of the plant in an organic supplemented soil environment will get the better result ${ }^{63}$. Clonal propagation of explants was achieved through callus free axillary meristem proliferation in $\mathrm{SH}$ medium from the stem node explants. Shoot multiplication increased by the result of cytokinin along with the synergetic effect of auxin. Five to 10 shoots was obtained in 5 to 6 weeks with the effect of $3.0 \mathrm{mg} . \mathrm{l}^{-1}$ BAP, $0.5 \mathrm{mg} . \mathrm{l}^{-1}$ 2-ip and $1.0 \mathrm{mg} . \mathrm{l}^{-1}$ IAA. Rooting was obtained in the medium containing $0.2 \mathrm{mg} . \mathrm{l}^{-1}$ IBA or IAA. Hardening the plants in humidity chamber showed $95 \%$ of survival rate. They flowered in 15 months with no cytological defects shows a good result of micropropagation ${ }^{[64]}$.

\section{Discussion}

J. beddomei, the plants are medicinally very important and its presence is inevitable. The detailed pharmacological activities about the phytochemicals found in J. beddomei are absent or insufficient. Primary phytochemical studies revealed the 
presence of several chemicals. Most of these chemicals are similar to $J$. adhatoda, which are efficient for the treatment of various disorders. Molecular studies revealed that these two plants emerged from a common ancestor, so shows the remarkable similarities. Recently in traditional medicine, $J$. adhatoda acquired its position. The unavailability of $J$. beddomei makes limited studies and restricted use in medicinal fields. The distribution of the plant is restricted at the elevation of $1000 \mathrm{~m}$, overexploitation for the medicinal and research purpose leads to the rapid depletion of this important plant from its natural habitat ${ }^{65}$. From 1998 the plant is listed in IUCN Red List as endangered and again the count is reduced to become critically endangered ${ }^{6,7}$. The conservation of the plants is very important for the development of the traditional medicinal system. Recent studies show that the phytochemicals found in J. beddomei are used against viral infected diseases such as COVID 19. The propagation of the plants is very difficult, so we have to develop new propagation strategies like tissue culture. The ecosystem is balanced because of the equal distribution of flora and fauna. The involvement of human being makes a disturbed ecosystem which will adversely affect the whole. The plant $J$. beddomei, not used as an adulterant or substitute, shows its effect on the medicinal field confronts adverse riddles from the ecosystem. The extinction of these types of medicinally important plants will lead to developing new strategies to conserve them.

\section{Conclusion}

From the current review, we concluded that the conservation of $J$. beddomei could be useful for the development of commercial as well as traditional drugs on a detailed exploration of phytochemicals and pharmacological actions after needful mass cultivation is practised.

\section{Acknowledgements}

The authors express their grateful acknowledgement to the Director In-charge, SCRI, Chennai and Prof Dr Kanakavalli, Director General, CCRS, Chennai for their support.

\section{Reference}

1. Jain SK. Ethnobotany: its scope in various subdisciplines. In: A manual of Ethnobotany, Scientific Publishers, Jodhpur 1987, 1-11.

2. Sharma A, Kumar A. Acanthaceae: Taxonomy and uses in traditional medicinal system. World Journal of Pharmaceutical Research 2016;5(7):403-12.

3. Durkee LH. Family\# 200. Acanthaceae. Flora Costaricensis (ed. W. Burger). Fieldiana, New Series 1986.

4. Mabberley DJ. The plant-book: a portable dictionary of the vascular plants, Cambridge university press 1997.

5. Rajasekhar D, Vanisree M, Subbaraju GV. Justicia Lignans: Two new aryl naphthalidelignans from Justicia neesii Ramamoorthy. Indian Journal of Chemistry. 1999;38:713 17.

6. http://envis.frlht.org/plantdetails/16e5fd73518f2062f0af2 8cee1df7ff2/ddcda1f74303cff8d8edd37461156a1f accessed on 17.04.2020

7. Rao CK, Geetha BL, Suresh GE. Red list of threatened vascular plant species in India. Botanical Survey of India, Kolkata 2003.

8. https://plants.jstor.org/stable/10.5555/al.ap.specimen.k00 0884079 accessed on 17.04.2020

9. Warrier PK, Nambiar VPK, Ramankutly C. Indian
Medicinal Plants, Vol3. Orient Longman Pvt. Ltd., Chennai 1994, 268.

10. Asolkar LV, Kakkar KK, Chakre OJ. Second supplement to Glossary of Indian Medicinal Plants with Active Principles", part-1. National Institute of Science Communication (CSIR), New Delhi 2000.

11. Gupta A, Prajapati PK. A clinical review of different formulations of vasa (Adhatoda vasica) on Tamakaswasa (asthma). AYU 2010;31(4):520-524.

12. Ignacimuthu $\mathrm{S}$, Shanmugham N. Antimycobacterial activity of two natural alkaloids, vasicine acetate and 2acetyl benzylamine, isolated from Indian shrub Adhatoda vasica Nees leaves. Journal of Bioscience 2010;35(4):565-570.

13. http://keralaplants.in/keralaplantsdetails.aspx $? \mathrm{id}=J$ usticia _beddomei accessed on 15.04.2020

14. Sasidharan N. (Dr. B P Pal Fellow), Kerala Forest Research Institute, Peechi.

15. Patil AM, Patil DA. Occurrence and significance of cystoliths in Acanthaceae. Current Botany 2011.

16. Srinivasan M, Padmaja B, Nair S. GC-MS profiling and in vitro radical scavenging effect of Adhatoda beddomei. Journal of Pharmacognosy and Phytochemistry 2014;2(5).

17. Harbone IB. Introduction to Ecological biochemistry. Edn 3. A cademic press, London 1988, 10-15.

18. https://herbs.indianmedicinalplants.info/index.php/a/1334 -adhatoda-beddomei-medicinal-uses-morphologyimages-side-effects-pharmacology accessed on 15.04.2020

19. Jain MP, Srivastava TN. Preliminary phytochemical studies on Adhatoda beddomei. Fitoterapia 1986.

20. Panigrahi J, Gantait S, Patel IC. Justicia beddomei, a source of comprehensive vasicinone production. Israel Journal of Plant Sciences 2019;1:1-7.

21. Marathakam A, et al. Studies on phytochemical and InVitro antioxidant potential of Justicia beddomei (Clarke) Bennett. Free Radicals and Antioxidants 2012;2(4):2631.

22. Krishnan K, Mani A, Jasmine S. Cytotoxic activity of bioactive compound 1,2-benzene dicarboxylic acid, mono 2-ethylhexyl ester extracted from a marine derived Streptomyces sp. VITSJK8. International journal of molecular and cellular medicine 2014;3(4):246.

23. Mehreen A, et al. Phytochemical, Antimicrobial, and Toxicological Evaluation of Traditional Herbs Used to Treat Sore Throat. Biomed Research International. 2016.

24. Latha, M, et al. Biocompatibility and antibacterial activity of the Adathoda vasica Linn. extract mediated silver nanoparticles. Microbial pathogenesis 2016;93:8894.

25. Gupta A, Prajapati PK. A clinical review of different formulations of Vasa (Adhatoda vasica) on Tamaka Shwasa (asthma). AYU 2010;31(4):520.

26. Swain SS, Sahu MC, Padhy RN. In silico attempt for adduct agent (s) against malaria: combination of chloroquine with alkaloids of Adhatoda vasica. Computer Methods and Programs in Biomedicine 2015;122(1):1625.

27. Armanian AM, et al. Prophylactic aminophylline for prevention of apnea at higher-risk preterm neonates. Iran Red Crescent Medical Journal 2014;16(8).

28. Farquhar JW, Sokolow M. Response of serum lipids and lipoproteins of man to beta-sitosterol and safflower oil: a long-term study. Circulation 1958;17(5):890-9. 
29. Berman J, et al. Nutritionally important carotenoids as consumer products. Phytochemistry Reviews 2014; 14:727-743.

30. Harasym J, Oledzki R. fruit and vegetable antioxidants on total antioxidant capacity of blood plasma. Nutrition 2014;30:511-517.

31. Zhang ZQ, et al. Greater serum carotenoid concentration associated with higher bone mineral density in Chinese adults. Osteoporosis International 2016;27:1593-1601.

32. Calderon MJ, et al. A review on the dietary flavonoid kaempferol. Mini reviews in medicinal chemistry. 2011;11(4):298-344.

33. Jemal A, et al. Cancer statistics, CA: A Cancer Journal for Clinicians 2007;57:43-66.

34. Bajgar J. Time course of acetylcholinesterase inhibition in the medulla oblongata of the rat by O-ethyl S-(2dimethylaminoethyl) methylphosphonothioate in vivo. British Journal of Pharmacology 1972;45(2):368.

35. Santos CC, et al. Antinociceptive and antioxidant activities of phytol in vivo and in vitro models. Neuroscience 2013.

36. Ryu KR, et al. Anti-scratching behavioral effect of the essential oil and phytol isolated from Artemisia princeps Pamp. in mice. Planta Medica 2011;77:22-26.

37. Lim SY, et al. Phytol-based novel adjuvants in vaccine formulation: 1. assessment of safety and efficacy during stimulation of humoral and cell-mediated immune responses. Journal of Immune Based Therapies and Vaccines 2006;4:6.

38. Huang ZR, Lin YK, Fang JY. Biological and pharmacological activities of squalene and related compounds: potential uses in cosmetic dermatology. Molecules 2009;14(1):540-54.

39. Ferrer A, et al. Emerging roles for conjugated sterols in plants. Progress in lipid research 2017;67:27-37.

40. Cabral CE, Klein MR. Phytosterols in the treatment of hypercholesterolemia and prevention of cardiovascular diseases. Arquivos Brasileiros de Cardiologia 2017;109(5):475-482.

41. Avula B, et al. Quantitative determination of vasicine and vasicinone in Adhatoda vasica by high performance capillary electrophoresis. Die Pharmazie-An International Journal of Pharmaceutical Sciences 2008;63(1):20-22.

42. Soni S, et al. Validation of different methods of preparation of Adhatoda vasica leaf juice by quantification of total alkaloids and vasicine. Indian Journal of Pharmeutical Science 2008;70(1):36.

43. Amin AH, Mehta DR. A bronchodilator alkaloid (vasicinone) from Adhatoda vasica Nees. Nature 1959;184(4695):1317.

44. Mehta DR, Naravane JS, Desai RM. Vasicinone. A bronchodilator principle from Adhatoda vasica Nees (NO Acanthaceae). Journal of Organic Chemistry 1963;28(2):445-8.

45. Bag A, Bag A. Treatment of COVID-19 patients: Justicia adhatoda leaves extract is a strong remedy for COVID19 - Case report analysis and docking based study. Chem Rxiv 2020.

46. Rizvi S, et al. The role of vitamin $\mathrm{E}$ in human health and some diseases. Sultan Qaboos University Medical Journal 2014;14(2):e157.

47. Padayatty SJ, et al. Vitamin $\mathrm{C}$ as an antioxidant: evaluation of its role in disease prevention. Journal of the American College of Nutrition 2003;22(1):18-35.

48. Prieto JM, Recio MC, Giner RM. Anti-inflammatory activity of $\beta$-sitosterol in a model of oxazolone induced contact-delayed-type hypersensitivity. Latin American and Caribbean Bulletin of medicinal and aromatic plants 2006;5:57-62

49. Ovesna Z, Vachalkova A, Horvathova K. Taraxasterol and beta-sitosterol: new naturally compounds with chemoprotective/chemopreventive effects. Neoplasma 2004;51:407-14

50. Zak A, et al. Beta-sitosterol in the treatment of hypercholesterolemia. Casopis lekaru ceskych 1990;129:1320-3.

51. Bouic PJ, et al. Beta- Sitosterol and beta-sitosterol glucoside stimulate human peripheral blood lymphocyte proliferation: implications for their use as an immunomodulatory vitamin combination. International Journal of Immunopharmacology 1996;18:693-700.

52. Srinivasa U, et al. Anthelmintic activity of leaves of Justicia beddomei. Ancient science of life 2007;26(3):1.

53. Srinivasa U et al. Analgesic activity of Justicia beddomei leaf extract. Ancient science of life 2007;27(2):14.

54. Marathakam A, Kannappan N. In vitro anticancer activity and xanthine oxidase inhibitory properties of Justicia beddomei. Journal of Pharma Research 2013;8(1):5370.

55. Srinivasa U, et al. Antidiabetic activity of Justicia beddomei leaves in alloxan induced diabetic rats. Journal of Research and Education in Indian Medicine 2008, 458.

56. Prabavathy D, Valli Nachiyar C. Cytotoxic potential and phytochemical analysis of Justicia beddomei and its endophytic aspergillus SP, Asian Journal of Pharmaceutical and Clinical Research 2013;6(5):159161.

57. Patel VK, Venkatakrishna-Bhatt H. In vitro study of antimicrobial activity of Adhatoda vasika Linn.(leaf extract) on gingival inflammation--a preliminary report. Indian Journal of Medical Sciences. 1984; 38(4):70-2.

58. Chakraborty A, Brantner AH. Study of alkaloids from Adhatoda vasica Nees on their anti-inflammatory activity. Phytotherapy Research 2001;15(6):532-4.

59. Wakhloo RL, et al. Safety of vasicine hydrochloride in human volunteers. Indian Journal of Pharmacology 1980;13:129.

60. Marathakam A, Kannappan N, Santhiagu A. Evaluation of hepatoprotective activity of methanolic extract of Justicia beddomei (Clarke) Bennett against INH and Rifampicin induced hepatotoxicity. American Journal of Pharm Tech Research 2014;4(1):869-78.

61. Chrungoo NK, et al. Establishing taxonomic identity and selecting genetically diverse populations for conservation of threatened plants using molecular markers. Current Science 2018;114(3):539.

62. Mathew AS, Patel KN, Shah BK. Investigation on antifeedant and anthelmientic potential of Adhatoda vasica Nees. Indian Journal of Natural Products and Resources 1998;14(1):11-6.

63. Panigrahi JI, Patel IC. Micropropagation of Adhatoda beddomei using nodal explant. European Academic Research 2014;2(9):12194-204.

64. Sudha CG, Seeni S. In vitro multiplication and field establishment of Adhatoda beddomei CB Clarke, a rare medicinal plant. Plant Cell Reports. 1994; 13(3-4):203-7.

65. Aiyer KN, Kolammal MM. Pharmacognosy of Ayurvedic drugs. Edn 1, Vil. VII Dept. of Pharmacognosy, University of Kerala, Trivandrum 1963, 102-105. 